\title{
Effect of Different Weed Management Practices on Growth and Yield of Brinjal (Solanum melongena L.)
}

\author{
Sumeetsingh $^{1 *}$, Kulbirsingh ${ }^{1}$, D.S. Khurana ${ }^{1}$ and V. Sardana ${ }^{2}$ \\ ${ }^{1}$ Department of Vegetable Science, PAU, Ludhiana-141004, Punjab, India \\ ${ }^{2}$ Department of Plant Breeding and Genetics, PAU, Ludhiana-141004, Punjab, India \\ *Corresponding author
}

\section{A B S T R A C T}

\begin{tabular}{|c|c|}
\hline $\mathbf{K}$ & \multirow{4}{*}{$\begin{array}{l}\text { The present investigation was undertaken to evaluate the effect of integrated weed } \\
\text { management practices on weeds as well as crop growth and yield parameters in brinjal cv. } \\
\text { BH- } 6747 \text { during 2012-13 at vegetable research farm, Punjab Agricultural University, } \\
\text { Ludhiana. The field experiment comprised of various chemicals (weedicides) and mulch. } \\
\text { All the weed management treatments significantly reduced the dry weight and count of } \\
\text { weeds. Among various treatments, black polyethylene mulch was excellent in controlling } \\
\text { weed population and it was followed by pre-emergence application of oxyflourofen @ } \\
0.15 \mathrm{~kg} / \mathrm{ha} \text { along with hand weeding } 45 \text { days after transplanting(DAT) with respect to dry } \\
\text { weight of weeds, plant height, number of branches, average fruit weight, fruits per plant, } \\
\text { fruit length and girth and total yield. Maximum cost benefit ratio was obtained with } \\
\text { oxyflurofen @ } 0.15 \mathrm{~kg} / \mathrm{ha} \text { along with hand weeding. }\end{array}$} \\
\hline & \\
\hline & \\
\hline & \\
\hline
\end{tabular}

\section{Introduction}

Brinjal (Solanum melongena L.) also known as eggplant or aubergine is an important commercial vegetable crop grown throughout the India mainly by small, marginal and resource-poor farmers. It is the second highest consumed vegetable in India after potato and is considered as poor man's vegetable. It is quite high in nutritive value and can be well compared with tomato and is consumed as a cooked vegetable in various ways.

Brinjal is cultivated in different seasons in different parts of country. The maximum area under this crop is during kharif season. Where success of crop depends on many factors and effective weed management is one of most prior for a successful crop. Favorable environmental conditions, its wider spacing and liberal use of farmyard manure, chemical fertilizers and frequent irrigations encourage the weeds to grow vigorously and lead to severe weed competition particularly during early stages of its growth. It has been estimated that losses in yield due to weeds alone vary from 10 to $70 \%$ depending upon the extent of weed infestation (Mani et al., 1968). It is difficult to control manually because of poor efficiency of the labour in summer and rainy season besides heavy cost of manual weeding. There seems to be good scope to make use of selective chemical and cultural control to attain season long control 
of weeds (Reddy et al., 2000). Mulching is often practiced in vegetables to effectively reduce moisture loss during hot summer months and to reduce soil erosion and nutrient loss (Clough et al., 1990). Mulching also provides effective control of weeds (Aniekwe et al., 2004). Black polyethylene mulch prevents sunlight from reaching the soil which helps to inhibit germination and growth of most of the weeds (Sinha, 2002). The present study was designed to investigate the feasibility of using mulch materials and herbicides as a weed control approach.

\section{Materials and Methods}

The present experiment was conducted at Vegetable Research Farm, Punjab Agricultural University, Ludhiana situated at $30^{\circ} 54^{\prime} \mathrm{N}$ latitude and $75^{\circ} 48^{\prime} \mathrm{E}$ longitude at a mean height of 247 meters above sea level. The experimental design was Randomized Complete Block Design with three replications having fifteen treatments comprising of hand weeding, mulching, pretransplanting treatments with trifluralin $(0.240$ $\mathrm{kg} / \mathrm{ha}$ and $0.300 \mathrm{~kg} / \mathrm{ha})$, pendimethalin $(0.56$ $\mathrm{kg} / \mathrm{ha}$ and $0.75 \mathrm{~kg} / \mathrm{ha})$, oxyfluorfen $(0.15$ $\mathrm{kg} / \mathrm{ha}$ and $0.20 \mathrm{~kg} / \mathrm{ha}$ ) and post-transplanting treatment with paraquat $(1.0 \mathrm{~kg} / \mathrm{ha})$ and unweeded check. Treatment details are given in Table 1 and 2. The desired herbicide was dissolved in 500 liters of water per hectare and was done by hand operated knap-sack sprayer with flat-fan nozzle. Trifluralin, pendimethalin and oxyfluorfen were applied as blanket spray whereas paraquat was applied as directed spray as per treatments. Observations on various growth and yield parameters of crop viz., plant height, number of branches per plant, number and weight of fruits per plant, fruit yield as well as observations on weeds such as weed count, dry matter of weeds and weed control efficiency as influenced by various treatments were recorded. The economics of these weed management practices were also worked out The data for each parameter were subjected to analysis of variance technique and the means were separated by LSD test (Steel and Torrie, 1981).

\section{Results and Discussion}

Weed species observed in the experimental fields were Cynodon dactylon, Eleusine indica, Cyperus rotundus, Phyllanthus niruri, Trianthema portulacastrum, Portulaca oleracea, Parthenium hysterophorus, Euphorbia hirta, Amaranthus viridi and Convolvulus arvensis. The effect of various weed control practices on weed number, weed dry matter accumulation, weed control efficiency and weed index are presented in Table 1. Maintaining weed free conditions and black mulch caused most significant reduction in number and dry matter production by weeds at 30, 60 and 90 DAT (Table 1). In herbicide based treatments minimum number and dry weight of weeds were obtained in oxyfluorfen (pre-emergence) @ $0.20 \mathrm{~kg} / \mathrm{ha}$ at 30 DAT followed by oxyfluorfen (pre-emergence) @ $0.15 \mathrm{~kg} / \mathrm{ha}+$ hoeing (45 DAT) at 60 and 90 DAT. The weed control efficiency of the treatment black polyethylene mulch was 97.56, 96.72 and 96.59 percent after 30, 60 and 90 DAT respectively while weed index was is -0.73 percent. Mulching with black polyethylene resulted in better weed control efficiency as soil was covered thoroughly so there was no space for weeds to grow. Manual weeding at 45 DAT showed better result followed by treatment comprising with post-emergence application of paraquat at 45 DAT, thus showing better result than other treatments. These findings are in line with similar results obtained by Nadagouda (1995). Among the herbicides oxyfluorfen was very effective in controlling the weeds and resulted in significantly higher weed control efficiency. 
Table.1 Effect of weed control treatments on weed count, weed dry weight, weed control efficiency at different intervals and weed index

\begin{tabular}{|c|c|c|c|c|c|c|c|c|c|}
\hline \multirow[t]{2}{*}{ Treatment } & \multicolumn{3}{|c|}{$\begin{array}{l}\text { Weed count } \\
\left(\text { number } / \mathrm{m}^{2} \text { ) }\right.\end{array}$} & \multicolumn{3}{|c|}{ Dry weight $\left(\mathrm{g} / \mathrm{m}^{2}\right)$} & \multicolumn{3}{|c|}{$\begin{array}{c}\text { Weed control efficiency } \\
(\%)\end{array}$} \\
\hline & $\begin{array}{c}30 \\
\text { DAT }\end{array}$ & $\begin{array}{c}60 \\
\text { DAT }\end{array}$ & $\begin{array}{c}90 \\
\text { DAT }\end{array}$ & $\begin{array}{c}30 \\
\text { DAT }\end{array}$ & $\begin{array}{c}60 \\
\text { DAT }\end{array}$ & $\begin{array}{c}90 \\
\text { DAT }\end{array}$ & $\begin{array}{c}30 \\
\text { DAT }\end{array}$ & $\begin{array}{c}60 \\
\text { DAT }\end{array}$ & $\begin{array}{c}90 \\
\text { DAT }\end{array}$ \\
\hline Pendimethalin (pre transplant) @ 0.56 kg/ha & 38.0 & 217.0 & 329.0 & 81.6 & 116.6 & 155.0 & 81.46 & 31.11 & 19.95 \\
\hline Pendimethalin (pre transplant) @ 0.75 kg/ha & 35.0 & 211.7 & 347.3 & 70.0 & 111.6 & 166.6 & 82.93 & 32.80 & 15.49 \\
\hline $\begin{array}{l}\text { Pendimethalin (pre transplant) } \\
\text { hoeing (45 DAT) }\end{array}$ & 40.7 & 91.0 & 209.7 & 71.6 & 55.3 & 81.6 & 80.16 & 71.11 & 48.99 \\
\hline $\begin{array}{l}\text { Pendimethalin (pre transplant) @ } 0.56 \mathrm{~kg} / \mathrm{ha}+ \\
\text { paraquat } 1.0 \mathrm{~kg} / \mathrm{ha} \text { (directed spray at } 45 \mathrm{DAT})\end{array}$ & 33.3 & 161.0 & 240.0 & 76.6 & 65.0 & 125.0 & 83.74 & 48.89 & 41.61 \\
\hline Oxyfluorfen (pre transplant) @ 0.15 kg/ha & 39.3 & 198.0 & 313.7 & 71.6 & 105.0 & 161.6 & 80.81 & 37.14 & 23.68 \\
\hline Oxyfluorfen (pre transplant) @ 0.20 kg/ha & 30.0 & 113.0 & 308.7 & 65.0 & 103.3 & 160.0 & 85.37 & 64.13 & 24.90 \\
\hline $\begin{array}{l}\text { Oxyfluorfen (pre transplant) @ } 0.15 \mathrm{~kg} / \mathrm{ha}+\text { hoeing } \\
\text { (45 DAT) }\end{array}$ & 33.7 & 86.3 & 190.3 & 40.0 & 71.3 & 68.3 & 83.58 & 72.59 & 53.69 \\
\hline $\begin{array}{l}\text { Oxyfluorfen (pre transplant) } @ \quad 0.15 \quad \mathrm{~kg} / \mathrm{ha} \\
\text { paraquat } 1.0 \mathrm{~kg} / \mathrm{ha} \text { (directed spray at } 45 \mathrm{DAT})\end{array}$ & 33.3 & 150.3 & 203.0 & 72.0 & 65.0 & 123.3 & 83.74 & 52.28 & 50.61 \\
\hline Trifluralin (pre transplant) @60 kg/ha & 43.3 & 207.6 & 342.0 & 88.3 & 110.0 & 143.3 & 78.86 & 34.07 & 16.79 \\
\hline Trifluralin (pre transplant) @ $0.90 \mathrm{~kg} / \mathrm{ha}$ & 40.0 & 191.6 & 324.0 & 75.0 & 91.6 & 108.3 & 85.49 & 39.15 & 21.17 \\
\hline $\begin{array}{l}\text { Trifluralin (pre transplant) @ } 0.60 \mathrm{~kg} / \mathrm{ha}+\text { hoeing } \\
\text { (45 DAT) }\end{array}$ & 41.3 & 112.3 & 206.3 & 83.6 & 62.0 & 95.0 & 89.84 & 64.34 & 49.80 \\
\hline $\begin{array}{l}\text { Trifluralin (pre transplant) @ } 0.60 \mathrm{~kg} / \mathrm{ha}+\text { paraquat } \\
1.0 \mathrm{~kg} / \mathrm{ha} \text { (directed spray at } 45 \mathrm{DAT})\end{array}$ & 40.7 & 161.0 & 276.0 & 85.0 & 63.6 & 105.0 & 80.16 & 48.89 & 32.85 \\
\hline Black mulch & 5.0 & 10.3 & 14.0 & 10.0 & 25.0 & 20.0 & 97.56 & 96.72 & 96.59 \\
\hline Weed free & 0.0 & 0.0 & 0.0 & 0.0 & 0.0 & 0.00 & 100.00 & $\begin{array}{c}100.0 \\
0\end{array}$ & 100.00 \\
\hline Un-weeded & 205.0 & 315.0 & 411.0 & 218.3 & 228.6 & 253.3 & 0.00 & 0.00 & 0.00 \\
\hline $\mathrm{CD}(\mathrm{P}=0.05)$ & 6.8 & 8.6 & 8.6 & 8.6 & 24.4 & 25.5 & - & - & - \\
\hline
\end{tabular}


Table.2 Effect of weed control treatments on growth, yield attributes, fruit yield of brinjal and cost benefit ratio

\begin{tabular}{|c|c|c|c|c|c|c|c|c|c|}
\hline \multirow[b]{2}{*}{ Treatment } & \multicolumn{3}{|c|}{ Plant height $(\mathrm{cm})$} & \multirow{2}{*}{$\begin{array}{l}\text { Number } \\
\text { of } \\
\text { branches }\end{array}$} & \multirow{2}{*}{$\begin{array}{l}\text { Average } \\
\quad \text { fruit } \\
\text { weight }(\mathrm{g})\end{array}$} & \multirow{2}{*}{$\begin{array}{l}\text { Fruits/ } \\
\text { plant }\end{array}$} & \multirow{2}{*}{$\begin{array}{l}\text { Fruit } \\
\text { girth } \\
(\mathrm{cm})\end{array}$} & \multirow{2}{*}{$\begin{array}{l}\text { Fruit } \\
\text { length } \\
(\mathrm{cm})\end{array}$} & \multirow{2}{*}{$\begin{array}{l}\text { Total } \\
\text { yield } \\
(\mathrm{q} / \mathrm{ha})\end{array}$} \\
\hline & $\begin{array}{c}30 \\
\text { DAT }\end{array}$ & $\begin{array}{c}60 \\
\text { DAT }\end{array}$ & $\begin{array}{c}90 \\
\text { DAT }\end{array}$ & & & & & & \\
\hline Pendimethalin (pre transplant) @ 0.56 kg/ha & 25.3 & 42.2 & 62.9 & 20.3 & 47.5 & 35.3 & 38.2 & 10.89 & 437.6 \\
\hline Pendimethalin (pre transplant) @ $0.75 \mathrm{~kg} / \mathrm{ha}$ & 24.6 & 40.2 & 60.2 & 21.6 & 48.9 & 36.2 & 36.8 & 10.22 & 438.7 \\
\hline $\begin{array}{l}\text { Pendimethalin (pre transplant) @ } 0.56 \mathrm{~kg} / \mathrm{ha} \\
+ \text { hoeing ( } 45 \mathrm{DAT})\end{array}$ & 23.3 & 42.8 & 62.8 & 22.5 & 48.5 & 37.4 & 40.0 & 12.56 & 482.2 \\
\hline $\begin{array}{l}\text { Pendimethalin (pre transplant) @ } 0.56 \mathrm{~kg} / \mathrm{ha} \\
\text { + paraquat } 1.0 \mathrm{~kg} / \mathrm{ha} \text { (directed spray at } 45 \\
\text { DAT) }\end{array}$ & 26.1 & 46.2 & 64.2 & 22.3 & 50.0 & 37.9 & 38.0 & 11.78 & 471.0 \\
\hline Oxyfluorfen (pre transplant) @ 0.15 kg/ha & 20.6 & 39.5 & 59.5 & 21.3 & 49.1 & 35.1 & 37.5 & 9.89 & 426.5 \\
\hline Oxyfluorfen (pre transplant) @ 0.20 kg/ha & 25.6 & 41.3 & 61.3 & 20.6 & 48.5 & 35.9 & 37.4 & 9.78 & 434.9 \\
\hline $\begin{array}{l}\text { Oxyfluorfen (pre transplant) @ } 0.15 \mathrm{~kg} / \mathrm{ha}+ \\
\text { hoeing (45 DAT) }\end{array}$ & 24.6 & 44.1 & 64.1 & 23.0 & 47.1 & 39.1 & 40.4 & 12.44 & 489.2 \\
\hline $\begin{array}{l}\text { Oxyfluorfen (pre transplant) @ } 0.15 \mathrm{~kg} / \mathrm{ha}+ \\
\text { paraquat } 1.0 \mathrm{~kg} / \mathrm{ha} \text { (directed spray at } 45 \\
\text { DAT) }\end{array}$ & 23.0 & 42.7 & 62.7 & 22.6 & 48.1 & 36.8 & 38.0 & 11.55 & 430.9 \\
\hline Trifluralin (pre transplant) @60 kg/ha & 22.1 & 43.1 & 61.1 & 19.6 & 48.5 & 35.2 & 36.8 & 9.22 & 409.9 \\
\hline Trifluralin (pre transplant) @ $0.90 \mathrm{~kg} / \mathrm{ha}$ & 20.5 & 40.7 & 60.7 & 21.0 & 47.0 & 36.2 & 36.5 & 10.00 & 424.2 \\
\hline $\begin{array}{l}\text { Trifluralin (pre transplant) @ } 0.60 \mathrm{~kg} / \mathrm{ha}+ \\
\text { hoeing (45 DAT) }\end{array}$ & 25.0 & 43.4 & 63.2 & 23.0 & 47.5 & 38.1 & 40.3 & 12.00 & 477.2 \\
\hline $\begin{array}{l}\text { Trifluralin (pre transplant) @ } 0.60 \\
\mathrm{~kg} / \mathrm{ha}+\text { paraquat } 1.0 \mathrm{~kg} / \mathrm{ha} \text { (directed spray at } \\
45 \text { DAT) }\end{array}$ & 23.1 & 40.6 & 60.6 & 22.0 & 48.0 & 38.4 & 37.8 & 11.78 & 472.1 \\
\hline Black mulch & 26.0 & 44.2 & 66.4 & 25.6 & 55.5 & 45.9 & 42.3 & 14.67 & 510.5 \\
\hline Weed free & 23.1 & 41.5 & 61.8 & 25.1 & 53.4 & 43.0 & 40.6 & 13.11 & 506.8 \\
\hline Un-weeded & 19.6 & 38.8 & 58.8 & 18.0 & 37.0 & 28.7 & 35.0 & 8.78 & 341.0 \\
\hline $\mathrm{C} \mathrm{D}(\mathrm{P}=0.05)$ & N.S & 3.6 & 2.6 & 1.7 & 6.6 & 2.7 & 1.6 & 0.91 & 4.2 \\
\hline
\end{tabular}


In present study it was noticed that plants gained maximum height of 44.2 and $66.4 \mathrm{~cm}$ after 60 and 90 DAT and number of branches recorded were 25.6 (Table 2). It was most probably due to the fact that in these plants due to lesser competition with weeds it encouraged growth of plant which was depicted in terms of better height and more number of branches.

With respect to yield parameters, significantly highest number of fruits per plant (45.9) and average weight of fruit $(55.5 \mathrm{~g})$ were recorded with black polyethylene mulch.There was significant difference in yield of plots influenced by different treatments. It was observed that maximum yield of $510.5 \mathrm{q} / \mathrm{ha}$ was obtained from plots which were influenced by black mulch which is significantly higher than other treated plots and was at par with weed free plots also. Among herbicides maximum yield of 489.2 $\mathrm{q} / \mathrm{ha}$ was obtained in oxyfluorfen (preemergence) @ $0.15 \mathrm{~kg} / \mathrm{ha}$ + hoeing (45 DAT) which was significantly higher than other chemically treated plots. The higher yield may be attributed to lower dry matter accumulation by weeds and decrease in their population that helped increasing the yield attributes which ultimately led to higher yield (Mekki et al., 2010).

It is important to study economics of the experiment as no technology can be recommended without knowing its economics. Maximum profit was achieved in oxyfluorfen (pre-emergence) @ $0.15 \mathrm{~kg} / \mathrm{ha}+$ hoeing (45 DAT) (1: 5.3) followed by trifluralin (pre-plant emergence) @ 0.90 $\mathrm{kg} / \mathrm{ha}+$ paraquat $1.0 \mathrm{~kg} / \mathrm{ha}$ (Directed spray at 45 DAT) (1: 5.2). Black plastic mulch showed cost: benefit of 1: 5.1.Black plastic mulch has performed best in the enhancement of the subsequent yield, indicating that the weeds were effectively controlled through the shadowing of the covered weeds disabling them to perform photosynthesis that reduced their competitiveness. But high cost of black mulch reduced cost benefit ratio. It is thus concluded from the present investigation that oxyfluorfen (pre-emergence) @ $0.15 \mathrm{~kg} / \mathrm{ha}+$ hoeing (45 DAT) is beneficial for weed management in brinjal and also improves the cost benefit ratio.

Weed has become a major problem in vegetable nurseries as well as in crops. In rainy season weeds effect crop very badly. Since, in this research trial black plastic mulch is concluded as best remedy for controlling weeds in brinjal nursery as well as crop but is not economically good as per high cost of mulch. Chemical treatments integrated with cultural practices are more viable for controlling weeds. So, it is concluded that there should be new approach for controlling weeds that is integrated weed management which is both economic as well as ecofriendly. Integrating weed management practices may help easy and economic removal of weed without harming the harmony of nature.

\section{References}

Aniekwe N L, Okereke O U and Anikwe M A N (2004) Modulating effect of black plastic mulch on the environment, growth and yield of cassava in a derived savanna belt of Nigeria. Tropicultura 22:185-90.

Clough G H, Locascio S J and Olson S M (1990) Yield of successively cropped polyethylene mulched vegetables as affected by irrigation methods and fertilization management. J Amer Soc Horti Sci 115: 884-87.

Mani V S, Gautam K C and Chakrabority (1968). Losses in crop yield in India due to weed growth. PANS (C) 142: 141-58.

Mekki BB, Faida AA and Kowthar G (2010) Effect of weed control treatments on 
yield and seed quality of some Canola cultivars and associated weeds in newly reclaimed sandy soils. AmericanEurasian J. Agri. \& Env. Sci.7 (2): 20209.

Nadagouda B T (1995) Integrated weed management in drill sown onion (Allium cepa L.). M.Sc. (Agri.) Thesis, Univ. Agric. Sci., Dharwad, Karnataka (India) Reddy C N, Reddy M D and Devi M P (2000) Efficiency of various herbicides on weed control and yield of brinjal. Indian
J of Weed Sci. 32: 150-52.

Sinha (2002) Effect of different weed management practices on growth, yield and quality parameters of ginger (Zingiber officinale Rosc.). Himachal $\mathbf{J}$ of Agri. Res.28: 30-33.

Steel R G D and Torrie J H (1981) Principles and Procedures of statistics. A biometrical approach. Tosho Printing Co. Tokyo Japan Pp 663.

\section{How to cite this article:}

Sumeetsingh, Kulbirsingh, D.S. Khurana and Sardana, V. 2017. Effect of Different Weed Management Practices on Growth and Yield of Brinjal (Solanum melongena L.). Int.J.Curr.Microbiol.App.Sci. 6(11): 3124-3129. doi: https://doi.org/10.20546/ijcmas.2017.611.366 